\title{
四 \\ The Pricing and Efficiency of Australian Treasury Bond Futures
}

\author{
Alex Frino ${ }^{1}$, William Peng He${ }^{2}$ \& Andrew Lepone ${ }^{1}$
}

\begin{abstract}
This paper examines the efficiency of the Treasury Bond futures market in Australia. We provide a comprehensive explanation of the method used to price, and evaluate efficiency of the 3 and 10 Year Australian Treasury Bond Futures contracts, against underlying bond baskets. Results indicate that the futures contracts exhibit minimal variation from their theoretical value. The average mispricing equates to 1.96 basis points for 3 Year and 1.19 basis points for 10 Year government bond futures contracts. However, during some periods (including the financial crisis of 2008), the bond futures contracts exhibit greater mispricing. Consistent with prior literature, we find a decreasing pattern of mispricing towards expiry, with the futures contract yields and average forward yields of the underlying bonds converging towards expiry. Further analysis reveals that volatility and time to expiry exhibit a significant positive relationship with the absolute level of mispricing.
\end{abstract}

Keywords: Treasury bank futures, Market Microstructure

JEL Classification: G13

\footnotetext{
${ }^{1}$ Macquarie University

Email: andrew.lepone@mgsm.edu.au

${ }^{2}$ University of Sydney

This research was funded by the Sydney Futures Exchange under Corporations Regulation 7.5.88(2). The authors would like to thank Kristye van de Geer at the Australian Securities Exchange for useful comments.
} 


\section{Introduction}

Financial futures have attracted a great deal of attention since the significant increase in derivatives trading which coincided with the deregulation of financial markets during the 1980s. The growth of futures markets activities is traditionally justified and associated with economic functions such as lower transaction costs, higher liquidity, price discovery, information exchange and as a market for investors to hedge and trade risk (Brailsford \& Hodgson 1997). This paper examines the efficiency of the Treasury Bond futures market in Australia. To date, the pricing method of government bond futures relative to their underlying in Australia has not been examined in academic literature. Efficiency in the futures area is especially interesting for two main reasons. First, futures prices are used in estimating future spot rates. Estimates of future spot rates are useful for testing interest rate theories and for developing bond valuation models (Elton et al 1984). Second, most of the literature on the efficiency of capital markets uses common equity returns. These studies are really a simultaneous test of efficiency and the appropriateness of a pre-specified valuation model (Elton et al 1984). The arbitrage we analyse does not require a valuation model, and thus is one of the few pure tests of efficiency.

The efficiency of bond futures markets is examined in the United States by Capozza and Cornell (1979), Cornell (1981), Lang and Rasche (1978), Poole (1978) Puglisi (1978). Rendleman and Carabini (1979), Vignola and Dale (1979). Literature suggests that this market is not perfectly efficient. Elton et al. (1984) tests the efficiency of U.S. treasury bill futures markets using intra-day data and finds profitable arbitrage opportunities. Poole (1978) finds that differences between futures prices and forward prices implied in spot bills are not of the magnitude to permit profitable arbitrage. Capozza and Cornell (1979) and Cornell (1981) find that the nearest term contract is priced efficiently, while longer term contracts tend to be under-priced. The extent of underpricing is directly related to the time remaining until the futures expire (Rendleman \& Carabini 1979).

Prior literature on the pricing of futures in Australia tends to focus on stock index futures, and neglects the subject on the efficiency of bond futures markets. Cummings \& Frino (2008) conduct an empirical analysis of the mispricing of stock index futures, and find that the timing of dividend announcements and the volatility of the index have significant effects in widening the arbitrage window for index futures. In the area of fixed income securities, Heaney and Layton (1996) examine the cost of carry relationship for the Australian 90 day bank accepted bill futures market in the 1980's. Co-integration tests are applied to test for deviations from the cost of carry relationship, but do not show the absolute level of mispricing and associated economic significance. They find that mispricing decreases in the latter half of the decade due to increased arbitrage activity from foreign banks. Brailsford and Hodgson (1997) provide an examination of stock index futures pricing in Australia. They document a frequent, but small, mispricing. The series is related to time-toexpiry, which is consistent with the arbitrage position having an option component, and has a positive association with both volatility from the overnight US market and contemporaneous futures market volatility.

This paper examines the pricing efficiency of the 3 and 10 Year Australian Treasury Bond futures market. It documents the pricing method of Treasury Bonds and their futures, and the pattern in price divergence between spot and futures to highlights the movement between futures and physical bonds over the life of the contract. Similar to stock index futures, Australian Treasury Bond Futures are settled against a basket of underlying constituent assets (government bonds instead of stocks), with the linkage between futures and underlying prices maintained by arbitrageurs. In the absence of basis risk and transaction costs, arbitrageurs close the gap between the price of the futures and physical assets 
whenever a profit opportunity arises. In this study, we compare the yield and value of futures contracts with that of the underlying bond basket.

The analysis covers 30 contract expiries of 3 and 10 Year Treasury Bond Futures listed on the Australian Securities Exchange (ASX) from March 2002 to June 2009. Australian 3 and 10 Year Treasury Bond Futures are the benchmark derivative products for investors trading and hedging medium to long term Australian Dollar interest rates. They provide an efficient way to gain exposure to the Australian debt market, and are ranked among the 10 most traded long term interest rate futures contracts in the world today. Compared with other financial instruments, the Treasury bond futures contract is relatively simple to price; hence one would expect the market for Treasury bill futures to be efficient (Rendleman \& Carabini 1979). However, the method of pricing and settling government bond futures contracts varies significantly across countries. For example, Government Bond Futures in the United States are settled against a deliverable grade bond adjusted for a conversion factor, while Australian Treasury Bond Futures are cash settled against the average price of a pre-determined basket of Commonwealth Government Bonds. One contribution of this study is to document the pricing of Australian Treasury Bond Futures against their underlying physical bonds. This method will then be used to assess the pricing efficiency of the futures contracts.

Results of the analysis indicate that the futures contracts exhibit minimal variation from their theoretical value. The average mispricing equates to 1.96 basis points for 3 year and 1.19 basis points for 10 year government bond futures contracts. However, during some periods (including the financial crisis of 2008), the mispricing of bond futures contracts was elevated. Consistent with prior literature, we find a decreasing pattern of mispricing towards expiry, with the futures contract yields and average forward yields of the underlying bonds converging towards expiry. Futures volatility also exhibits a significant positive relationship with the absolute level of mispricing. Results indicate that the pricing error is generally negative, due to the more expensive transaction costs boundary which involves short selling the underlying bonds.

The remaining parts of this paper are organised as follows. Section 2 describes the institutional setting and data. Section 3 explains the methodology of calculating forward and futures prices. The empirical results are presented in Section 4, followed by the conclusion in Section 5.

\section{Institutional Detail and Data}

Australian 3 and 10 Year Treasury Bond Futures are the benchmark interest rate derivative products traded on the ASX. As one of the world's top-10 listed exchanges measured by capitalisation, the ASX was created through the merger of the Australian Stock Exchange and the Sydney Futures Exchange (SFE). The trading time for 3 and 10 Year Commonwealth Government Bond Futures are 5:10pm-7:00am \& 8:30am-4:30pm (US daylight saving) and 5:10pm-7:30am \& 8:30am-4:30pm (US non-daylight saving). The near contract ceases at 12pm on the expiry date. Settlement occurs on the next business day following the final trading day. There are four contract maturities every year, expiring on the $15^{\text {th }}$ of March, June, September and December. ${ }^{3}$ Australian Commonwealth Government Bond Futures have a face value of $\$ 100,000$ and a coupon of $6 \%$ for contracts listed since the September 2001 contract. The sample includes 30 futures expiries from March 2002 to June 2009. The data relate only to the near-dated futures contracts, because they typically are the heaviest traded contract, and therefore this contract is least likely to suffer from thin trading.

\footnotetext{
${ }^{3}$ If the $15^{\text {th }}$ is not a business day, then the next business day following the $15^{\text {th }}$.
} 
The SFE's 3 and 10 Year Commonwealth Government Bond Futures contracts are priced against underlying baskets of physical bonds. Prior to listing a contract, the Exchange determines the relevant bonds to be included in the basket according to their characteristics and market conditions. The bonds that constitute the underlying bond basket for each contract are shown in Table 1. The constituents for the bond baskets for the 3 and 10 Year Commonwealth Government Bond futures contracts are determined based on:

1) Time to Maturity - Bonds eligible for the 3 and 10 Year Commonwealth Government Bond contracts should mature in approximately two to four years, and seven and a half to twelve years, respectively.

2) Amount on Issue - Only those bonds that display a high degree of liquidity are used in the formation of bond baskets, as bonds with lower liquidity may be susceptible to manipulation.

3) Number of Bonds in Baskets - Exchange By-Laws, TB.4(a) and TRB.4(a), require any and all bond baskets to contain at least three bond series. As shown in Table 1, each futures contract is based on three or four physical bonds over the sample period.

4) Average Length to Maturity - The average length to maturity of the 3 Year Commonwealth Government Bond basket should range between two and a half years and three and a half years, while the 10 Year Commonwealth Government Bond basket should lie between nine years three months and ten years five months.

Table 1

Australian Treasury Bond Futures Underling Bond Basket

Table 1: Australian Treasury Bond Futures Underlying Bond Basket

\begin{tabular}{|c|c|c|c|c|c|c|c|c|c|}
\hline \multirow[b]{2}{*}{ Futures } & \multicolumn{4}{|c|}{ Panel A: 3 Year CGB } & \multirow[b]{2}{*}{ Futures } & \multicolumn{4}{|c|}{ Panel A: 10 Year CGB } \\
\hline & Bond 1 & Bond 2 & Bond 3 & Bond 4 & & Bond 1 & Bond 2 & Bond 3 & Bond 4 \\
\hline Mar-02 & $9 \%$ Sep 2004 & $7.5 \%$ July 2005 & $6.75 \%$ Nov 2006 & & Mar-02 & $7.5 \%$ Sep 2009 & $5.75 \%$ Jun 2011 & $6.5 \%$ May 2013 & \\
\hline Jun-02 & 9\% Sep 2004 & 7.5\% July 2005 & $6.75 \%$ Nov 2006 & & Jun-02 & $7.5 \%$ Sep 2009 & 5.75\% Jun 2011 & 6.5\% May 2013 & \\
\hline Sep-02 & $9 \%$ Sep 2004 & 7.5\% July 2005 & $6.75 \%$ Nov 2006 & & Sep-02 & 7.5\% Sep 2009 & 5.75\% Jun 2011 & 6.5\% May 2013 & \\
\hline Dec-02 & $9 \%$ Sep 2004 & 7.5\% July 2005 & $6.75 \%$ Nov 2006 & & Dec-02 & $7.5 \%$ Sep 2009 & $5.75 \%$ Jun 2011 & 6.5\% May 2013 & \\
\hline Mar-03 & 7.5\% July 2005 & 6.75\% Nov 2006 & $8.75 \%$ Aug 2008 & & Mar-03 & $5.75 \%$ Jun 2011 & 6.5\% May 2013 & 6.25\% Apr 2015 & \\
\hline Jun-03 & 7.5\% July 2005 & 6.75\% Nov 2006 & 8.75\% Aug 2008 & & Jun-03 & $5.75 \%$ Jun 2011 & 6.5\% May 2013 & 6.25\% Apr 2015 & \\
\hline Sep-03 & 7.5\% July 2005 & $6.75 \%$ Nov 2006 & 8.75\% Aug 2008 & & Sep-03 & $5.75 \%$ Jun 2011 & 6.5\% May 2013 & 6.25\% Apr 2015 & \\
\hline Dec-03 & 7.5\% July 2005 & $6.75 \%$ Nov 2006 & $8.75 \%$ Aug 2008 & & Dec-03 & $5.75 \%$ Jun 2011 & 6.5\% May 2013 & 6.25\% Apr 2015 & \\
\hline Mar-04 & 7.5\% July 2006 & 6.75\% Nov 2007 & $8.75 \%$ Aug 2009 & & Mar-04 & 5.75\% Jun 2011 & 6.5\% May 2013 & 6.25\% Apr 2015 & \\
\hline Jun-04 & $6.75 \%$ Nov 2007 & 8.75\% Aug 2008 & $7.5 \%$ Sep 2009 & & Jun-04 & $5.75 \%$ Jun 2011 & 6.5\% May 2013 & 6.25\% Apr 2015 & \\
\hline Sep-04 & $6.75 \%$ Nov 2007 & 8.75\% Aug 2008 & 7.5\% Sep 2009 & & Sep-04 & $5.75 \%$ Jun 2011 & 6.5\% May 2013 & 6.25\% Apr 2015 & \\
\hline Dec-04 & $6.75 \%$ Nov 2007 & 8.75\% Aug 2008 & 7.5\% Sep 2009 & & Dec-04 & 6.5\% May 2013 & 6.25\% Apr 2015 & 6\% Feb 2017 & \\
\hline Mar-05 & $6.75 \%$ Nov 2007 & 8.75\% Aug 2008 & 7.5\% Sep 2009 & & Mar-05 & $6.5 \%$ May 2013 & 6.25\% Apr 2015 & 6\% Feb 2017 & \\
\hline Jun-05 & 8.75\% Aug 2008 & 7.5\% Sep 2009 & $5.25 \%$ Aug 2010 & & Jun-05 & 6.5\% May 2013 & 6.25\% Apr 2015 & 6\% Feb 2017 & \\
\hline Sep-05 & 8.75\% Aug 2008 & 7.5\% Sep 2009 & 5.25\% Aug 2010 & & Sep-05 & 6.5\% May 2013 & 6.25\% Apr 2015 & 6\% Feb 2017 & \\
\hline Dec-05 & 8.75\% Aug 2008 & 7.5\% Sep 2009 & $5.25 \%$ Aug 2010 & & Dec-05 & $6.5 \%$ May 2013 & 6.25\% Apr 2015 & 6\% Feb 2017 & \\
\hline Mar-06 & 8.75\% Aug 2008 & 7.5\% Sep 2009 & $5.25 \%$ Aug 2010 & & Mar-06 & 6.5\% May 2013 & 6.25\% Apr 2015 & 6\% Feb 2017 & \\
\hline Jun-06 & 8.75\% Aug 2008 & 7.5\% Sep 2009 & $5.25 \%$ Aug 2010 & & Jun-06 & 6.5\% May 2013 & 6.25\% Apr 2015 & 6\% Feb 2017 & \\
\hline Sep-06 & $8.75 \%$ Aug 2008 & 7.5\% Sep 2009 & $5.25 \%$ Aug 2010 & & Sep-06 & 6.25\% Apr 2015 & 6\% Feb 2017 & $5.25 \%$ Mar 2019 & \\
\hline Dec-06 & 7.5\% Sep 2009 & 5.25\% Aug 2010 & $5.75 \%$ Jun 2011 & & Dec-06 & 6.25\% Apr 2015 & 6\% Feb 2017 & $5.25 \%$ Mar 2019 & \\
\hline Mar-07 & $7.5 \%$ Sep 2009 & 5.25\% Aug 2010 & 5.75\% Jun 2011 & & Mar-07 & $6.25 \%$ Apr 2015 & 6\% Feb 2017 & $5.25 \%$ Mar 2019 & \\
\hline Jun-07 & $7.5 \%$ Sep 2009 & 5.25\% Aug 2010 & 5.75\% Jun 2011 & & Jun-07 & 6.25\% Apr 2015 & 6\% Feb 2017 & $5.25 \%$ Mar 2019 & \\
\hline Sep-07 & 7.5\% Sep 2009 & 5.25\% Aug 2010 & 5.75\% Jun 2011 & & Sep-07 & 6.25\% Apr 2015 & 6\% Feb 2017 & 5.25\% Mar 2019 & \\
\hline Dec-07 & $7.5 \%$ Sep 2009 & 5.25\% Aug 2010 & $5.75 \%$ Jun 2011 & 5.75\% Apr 2012 & Dec-07 & 6.25\% Apr 2015 & 6\% Feb 2017 & $5.25 \%$ Mar 2019 & \\
\hline Mar-08 & $5.25 \%$ Aug 2010 & $5.75 \%$ Jun 2011 & 5.75\% Apr 2012 & & Mar-08 & 6.25\% Apr 2015 & 6\% Feb 2017 & $5.25 \%$ Mar 2019 & \\
\hline Jun-08 & $5.25 \%$ Aug 2010 & 5.75\% Jun 2011 & 5.75\% Apr 2012 & & Jun-08 & 6.25\% Apr 2015 & 6\% Feb 2017 & 5.25\% Mar 2019 & 5.75\% May 2021 \\
\hline Sep-08 & 5.25\% Aug 2010 & 5.75\% Jun 2011 & 5.75\% Apr 2012 & & Sep-08 & 6.25\% Apr 2015 & 6\% Feb 2017 & 5.25\% Mar 2019 & 5.75\% May 2021 \\
\hline Dec-08 & 5.25\% Aug 2010 & $5.75 \%$ Jun 2011 & 5.75\% Apr 2012 & 6.5\% May 2013 & Dec-08 & 6\% Feb 2017 & $5.25 \%$ Mar 2019 & $5.75 \%$ May 2021 & \\
\hline Mar-09 & 5.75\% Jun 2011 & 5.75\% Apr 2012 & 6.5\% May 2013 & & Mar-09 & 6\% Feb 2017 & 5.25\% Mar 2019 & $5.75 \%$ May 2021 & \\
\hline Jun-09 & $5.75 \%$ Jun 2011 & 5.75\% Apr 2012 & 6.5\% May 2013 & & Jun-09 & 6\% Feb 2017 & 5.25\% Mar 2019 & $5.75 \%$ May 2021 & \\
\hline
\end{tabular}

Table 1 presents the composition of the bond baskets underlying the 3 and 10 year Australian Commonwealth Government Bond Futures by contract expiries. The sample includes 30 contract expiries from March 2002 to June 2009. It shows the bonds, their coupon rate and expiry time that underlie each futures contract.

Market participants generally prefer bond baskets to remain unchanged for as long as possible. When underlying bonds are changed, new baskets are selected with an average 
length to maturity at the higher range of limits, and typically remain unchanged until they approach the lower range of limits. This is evident in Table 1, where the underlying bonds remain consistent for several consecutive expiries.

To price the physical bonds underlying the futures contracts, quotes on Australian Treasury Bond yields are obtained from the statistics section of the Reserve Bank of Australia (RBA) website for the period 15 December, 2001 through 15 June, 2009. This contains the daily closing prices of all the constituent bonds underlying the bond futures contracts, quoted as the percentage yield. In this study, we use the cash rate from the RBA website to proxy for the overnight repo rate.

Daily price data for futures contracts are collected for the period 15 December, 2001 through 15 June, 2009. It includes daily high, low, close prices and trading volume. This covers the 3 month period till expiry of the sample contracts: from March 2002 to June 2009. 3 Year and 10 Year Treasury Bond Futures are traded on the basis of their yield, with the futures price quoted as 100 minus the yield to maturity expressed in percent per annum, and therefore have Variable Tick Value. Due to this convention, the dollar value of the minimum price movement, or tick value, does not remain constant, but rather changes in accordance with movements in the underlying interest rate.

\section{Method}

To determine whether Treasury bond futures are mispriced, we compare the price quoted for the futures against the forward price of the underlying. Since there are four contract expiries in every year, each contract covers three months prior to its expiry. However, each contract is listed for trading 6 months before its expiry date, and hence contracts overlap in their listed period. In this study, only the futures contract closest-to-expiry is examined, because there is often no liquidity and little trading in the longer maturity contract.

The first step is to compute the value of the physical bonds underlying the futures contract. The formula for calculating the price per $\$ 100$ of an Australian Commonwealth Treasury Bond, as supplied by the RBA, is

$$
S_{\text {bond }}=v^{f / d}\left(c+g a_{n}+100 v^{n}\right)
$$

where $\mathrm{v}=1 /(1+\mathrm{i}) ; \mathrm{i}=$ the spot percentage yield divided by 200 ;

$\mathrm{f}=$ the number of days from the date of settlement to the next interest payment date;

$\mathrm{d}=$ the number of days in the half year ending on the next interest payment date;

$\mathrm{c}=$ the amount of interest payment per $\$ 100$ face value at the next interest payment date;

$\mathrm{g}=$ the fixed half-yearly interest rate payable (equal to the annual fixed rate divided by 2);

$\mathrm{n}=$ the number of full half-years between the next interest payment date and the date of maturity (Equal to 2 times the number of years until maturity); $\mathrm{a}_{\mathrm{n}}=\mathrm{v}+\mathrm{v}+\ldots \ldots+\mathrm{v}_{\mathrm{n}}=\left(1-\mathrm{v}_{\mathrm{n}}\right) / \mathrm{i}_{\mathrm{n}}$

Once the spot value of the underlying bond is determined, the forward value is calculated using a cost of carry model. The theoretical price of the forward value is as follows:

$$
f_{t, T}=\left(S_{t}-c\right) e^{r(T-t)}
$$

where $f_{t, T}$ is the current price of the futures contract expiring at time $T$ with zero dividend yield;

$S_{t}$ is the current bond price;

$r$ is the annualised cash rate over the period from time $t$ to time $T$;

$T-t$ is the time to maturity of the contract;

$c$ is the coupon that will be paid before futures expiry. 
The next step is to calculate the implied yield of the forward value of the bond. We solve this by iteratively solving for the internal rate of return in the following equation. The resolution uses the Newton method of iteration to calculate the implied yield. The yield is changed until the estimated price is reached.

$$
F_{\text {bond }}=v^{\prime f^{\prime} / d^{\prime}}\left(c+g a_{n}^{\prime}+100 v^{\prime n}\right)
$$

where $\mathrm{v}^{\prime}=1 /\left(1+\mathrm{i}^{\prime}\right) ; \mathrm{i}^{\prime}=$ the forward percentage yield divided by 200 ;

$\mathrm{f}^{\prime}=$ the number of days from the futures expiry date to the next interest payment date;

$\mathrm{d}^{\prime}=$ the number of days in the half year ending on the next interest payment date;

$\mathrm{c}=$ the amount of interest payment per $\$ 100$ face value at the next interest payment date;

$\mathrm{g}=$ the fixed half-yearly interest rate payable (equal to the annual fixed rate divided by 2);

$\mathrm{n}=$ the number of full half-years between the next interest payment date and the date of maturity (Equal to 2 times the number of years until maturity);

$\mathrm{a}_{\mathrm{n}}{ }^{\prime}=\mathrm{v}^{\prime}+\mathrm{v}^{\prime}+\ldots \ldots+\mathrm{v}_{\mathrm{n}}{ }^{\prime}=\left(1-\mathrm{v}_{\mathrm{n}}{ }^{\prime}\right) / \mathrm{i}_{\mathrm{n}}{ }^{\prime}$

The above steps are performed individually for the constituent bonds in the underlying basket. The implied forward yields are then averaged to reach the theoretical yield for the futures contract. This is compared to the futures yield (Futures Yield $=100-$ Future Quote) to determine the mispricing of the futures contract against the physical bond basket in terms of basis points. Negative (positive) divergence means that the underlying bonds are more (less) expensive than the futures.

Mispricing = Average Forward Yield of Bond Basket - Futures Contract Yield

3 Year and 10 Year Treasury Bond Futures are quoted on the basis of their yield and therefore have Variable Tick Value. Due to this convention, the change in dollar value of the contracts does not remain constant with changes in yields. Therefore each basis point mispricing cannot be directly converted into differences in contract value. To assess the economic significance of the mispricing, we evaluate the magnitude of deviation in terms of percentage difference in contract value.

For ASX Treasury Bond futures, the pricing formula can be simplified because there is always an exact number of half years to maturity, and hence there is no requirement to calculate accrued interest. The formula for the value (P) of 3 and 10 Year Bond futures contracts on the ASX are written as:

$$
\begin{gathered}
P_{3}=1000 \times\left[\frac{c\left(1-v^{6}\right)}{i}\right]+100 v^{6} \\
P_{10}=1000 \times\left[\frac{c\left(1-v^{20}\right)}{i}\right]+100 v^{20}
\end{gathered}
$$

where $\mathrm{i}=$ yield $\%$ p.a. divided by 200 ;

$\mathrm{v}=1 /(1+\mathrm{i}) ; \mathrm{n}=20$;

$\mathrm{c}=$ coupon rate $/ 2$.

The futures contract value is calculated using the quoted futures yield, and the implied forward yield to evaluate the percentage difference in value as a result of the yield differential.

$$
\frac{\left(P_{\text {forward }}-P_{\text {futures }}\right)}{P_{\text {forward }}}=\text { Mispricing\% }
$$

This provides an indication of the economic significance of the mispricing as a result of the disparity between yields.

To explain the mispricing series, both time series and regression based approaches are employed. The behaviour of the mispricing series in relation to market volatility and time to expiry is examined. The following regression is estimated for the 3 and 10 year government 
bond futures. After controlling for day of the week and expiry cycles, volatility of futures prices and time-to-expiry of contracts are regressed on the level of mispricing.

$$
\text { Mispricing }_{i t}=a_{1}+\sum_{d=1}^{4} c_{d} \text { Days }_{i t}+\sum_{e=5}^{7} c_{e} \text { Quarters }_{i t}+c_{8} \text { TTE }_{i t}+c_{9} \text { Volatility }_{i t}
$$

The dependent variable Mispricing is defined as the absolute value of mispricing between the futures yield and the implied forward yield of the underlying contracts in terms of basis points. Days are zero-one dummy variables to test whether there are systematic and fixed mispricing patterns related to each day of the week. Quarters are zero-one dummy variables to test whether there are systematic and fixed mispricing patterns related to different expiry cycles. TTE is time-to-expiry, measured by the number of trading days before a contract expires. Volatility is the natural logarithm of highest price divided by lowest price on the day.

\section{Results}

To examine the efficiency of the ASX 3 and 10 Year Treasury Bond Futures, we compare the yields and value of the futures with the underlying baskets of physical bonds. The time-toexpiry pattern of mispricing for the 3 and 10 Year Commonwealth Government Bond Futures are depicted in Figure 1. We find a decreasing pattern of mispricing towards expiry. For the 10 Year Treasury Bond Futures, the average mispricing is approximately 1.5 basis points at the start of period. It slowly decreases and approaches zero at expiry. For the 3 Year Treasury Bond Futures, the average mispricing is approximately 3.2 basis points at the start of period, and approaches zero at expiry. Although the 3 year contracts incur greater pricing inefficiency measured in terms of basis points, the longer duration of the 10 year contracts means that each basis point deviation translates to greater mispricing in terms of dollar value. Therefore it is expected that the 10 year contracts exhibit less basis point deviation than the 3 year contracts.

Figure 1

Time to Expiry Patterns of Mispricing



Figure 1 shows the time-to-expiry pattern of mispricing of 3 and 10 year Australian Commonwealth Government Bond Futures. The sample includes 30 contract expiries from March 2002 to June 2009. The lines depict the basis points misprising of futures quoted up to 65 trading days to expiry (Yield Divergence $=$ Average Forward Yield of Bond Basket - 
Futures Contract Yield). Negative (positive) divergence means that the underlying bonds are more (less) expensive than the futures.

The pricing efficiency of the individual bond futures contracts are documented in Table 2 which presents the average mispricing in basis points between the futures rate and the forward rate and its standard deviation. The results also show the percentage difference in value of the futures contract that the basis points translate into. The results for 3 year bond futures contracts are shown in Panel A, while the results for 10 year bond futures contracts are shown in Panel B. We find small mispricing in all of the 3 Year Treasury Bond Futures, measured by absolute differences in yields, and as percentage difference in contract value. The maximum contract mispricing is 6.75 basis points, which translates to $0.187 \%$ of the futures contract value. Both 3 and 10 year bond futures show greater mispricing during the financial crisis of 2008, when risk and volatility in the markets were elevated. Due to a shortage of physical government bonds, their yields were generally lower than the futures yields.

During the height of the financial crisis, the demand for government bonds increased, causing the underlying bond to be more expensively priced than the futures contracts. We find small mispricing in most of the 10 Year Treasury Bond Futures, measured by absolute differences in yields, and as percentage differences in contract value. However, the contracts that expire in March and June of 2007 and 2008 show higher mispricing. They show mispricing between 4.46 and 6.49 basis points, which translates to between $0.332 \%$ and $0.478 \%$ of the futures contract value.

Table 2

3 and 10 Year Australian Commonwealth Government Bonds Pricing: Spot vs Futures Markets (by Contract)

\begin{tabular}{|c|c|c|c|c|c|c|c|c|}
\hline \multirow[b]{3}{*}{ Contract } & \multicolumn{4}{|c|}{ Panel A: 3 Year CGB } & \multicolumn{4}{|c|}{ Panel B: 10 Year CGB } \\
\hline & \multicolumn{3}{|c|}{ Average } & \multirow{2}{*}{$\begin{array}{c}\text { Percentage } \\
\text { Difference } \\
\text { in Value }\end{array}$} & \multicolumn{3}{|c|}{ Average } & \multirow{2}{*}{$\begin{array}{r}\text { Percentag } \\
\text { Difference } \\
\text { in Value }\end{array}$} \\
\hline & $\begin{array}{c}\text { Average } \\
\text { Mispricing }\end{array}$ & $\begin{array}{l}\text { Absolute } \\
\text { Mispricing }\end{array}$ & $\begin{array}{l}\text { Standard } \\
\text { Deviation }\end{array}$ & & $\begin{array}{c}\text { Average } \\
\text { Mispricing }\end{array}$ & $\begin{array}{l}\text { Absolute } \\
\text { Mispricing }\end{array}$ & $\begin{array}{l}\text { Standard } \\
\text { Deviation }\end{array}$ & \\
\hline Mar-02 & $\begin{array}{l}-2.98 \\
\end{array}$ & 2.98 & 1.12 & $0.081 \%$ & -1.28 & 1.28 & 0.46 & $0.095 \%$ \\
\hline Jun-02 & -2.13 & 2.13 & 0.99 & $0.058 \%$ & -0.72 & 0.72 & 0.49 & $0.053 \%$ \\
\hline Sep-02 & -1.35 & 1.35 & 0.58 & $0.037 \%$ & 2.38 & 2.38 & 0.44 & $-0.178 \%$ \\
\hline Dec-02 & -2.39 & 2.39 & 1.21 & $0.065 \%$ & -0.43 & 0.43 & 0.43 & $0.041 \%$ \\
\hline Mar-03 & -1.05 & 1.05 & 0.86 & $0.029 \%$ & -0.88 & 0.88 & 0.42 & $0.067 \%$ \\
\hline Jun-03 & -1.25 & 1.25 & 0.92 & $0.034 \%$ & -0.82 & 0.82 & 0.37 & $0.062 \%$ \\
\hline Sep-03 & -2.94 & 2.94 & 1.04 & $0.080 \%$ & -1.22 & 1.22 & 0.50 & $0.092 \%$ \\
\hline Dec-03 & -4.80 & 4.80 & 1.40 & $0.130 \%$ & -2.70 & 2.70 & 0.45 & $0.202 \%$ \\
\hline Mar-04 & -2.37 & 2.37 & 3.21 & $0.065 \%$ & -0.71 & 0.71 & 0.41 & $0.053 \%$ \\
\hline Jun-04 & -4.16 & 4.16 & 1.94 & $0.114 \%$ & -1.18 & 1.18 & 0.54 & $0.088 \%$ \\
\hline Sep-04 & -3.04 & 3.04 & 1.13 & $0.083 \%$ & -0.94 & 0.94 & 0.51 & $0.070 \%$ \\
\hline Dec-04 & -1.81 & 1.81 & 1.09 & $0.049 \%$ & -0.46 & 0.46 & 2.45 & $0.043 \%$ \\
\hline Mar-05 & -1.56 & 1.56 & 0.74 & $0.042 \%$ & -0.63 & 0.63 & 0.33 & $0.051 \%$ \\
\hline Jun-05 & -2.10 & 2.10 & 1.06 & $0.055 \%$ & -0.69 & 0.69 & 0.38 & $0.057 \%$ \\
\hline Sep-05 & -1.53 & 1.53 & 0.94 & $0.042 \%$ & -1.02 & 1.02 & 0.44 & $0.077 \%$ \\
\hline Dec-05 & -1.72 & 1.72 & 0.89 & $0.047 \%$ & -0.88 & 0.88 & 0.37 & $0.066 \%$ \\
\hline Mar-06 & -0.91 & 0.91 & 0.58 & $0.025 \%$ & -1.09 & 1.09 & 0.56 & $0.083 \%$ \\
\hline Jun-06 & -1.22 & 1.22 & 0.72 & $0.033 \%$ & -0.90 & 0.90 & 0.47 & $0.069 \%$ \\
\hline Sep-06 & 0.18 & 0.18 & 0.68 & $-0.005 \%$ & 0.04 & 0.04 & 0.30 & $-0.003 \%$ \\
\hline Dec-06 & -0.45 & 0.45 & 0.58 & $0.012 \%$ & -0.01 & 0.01 & 0.30 & $0.000 \%$ \\
\hline Mar-07 & 0.05 & 0.05 & 0.49 & $-0.001 \%$ & -4.46 & 4.46 & 0.30 & $0.332 \%$ \\
\hline Jun-07 & -0.26 & 0.26 & 0.44 & $0.007 \%$ & -4.49 & 4.49 & 0.31 & $0.334 \%$ \\
\hline Sep-07 & -0.45 & 0.45 & 0.54 & $0.012 \%$ & -1.48 & 1.48 & 0.29 & $0.110 \%$ \\
\hline Dec-07 & -0.50 & 0.50 & 0.69 & $0.014 \%$ & -0.34 & 0.34 & 0.43 & $0.025 \%$ \\
\hline Mar-08 & -2.18 & 2.18 & 1.69 & $0.059 \%$ & -5.40 & 5.40 & 1.53 & $0.400 \%$ \\
\hline Jun-08 & -4.64 & 4.64 & 2.38 & $0.125 \%$ & -6.49 & 6.49 & 1.03 & $0.479 \%$ \\
\hline Sep-08 & -3.21 & 3.21 & 1.69 & $0.087 \%$ & -2.43 & 2.43 & 0.95 & $0.180 \%$ \\
\hline Dec-08 & -6.75 & 6.75 & 3.19 & $0.187 \%$ & 1.21 & 1.21 & 1.32 & $-0.090 \%$ \\
\hline
\end{tabular}


Table 2 presents the mispricing of 3 and 10 year Australian Commonwealth Government Bond Futures by contract expiries. The sample includes 30 contract expiries from March 2002 to June 2009. (Yield Divergence = Average Forward Yield of Bond Basket - Futures Contract Yield). Negative (positive) divergence means that the underlying bonds are more (less) expensive than the futures. The table shows average mispricing, absolute mispricing and standard deviation in terms of basis points. The last column of each panel shows the mispricing in terms of percentage difference in value that arises from the yield divergence.

The existence of a differential between the forward and futures rate does not imply that arbitrage will occur if transactions are costly. The arbitrageur needs to make multiple round trip transactions (for the physical bonds in the basket and the futures contract) to profit from the inefficiency. Transaction costs are not incorporated in the cost-of-carry. They may include brokers' fees, duties, exchange levies, short selling costs and implicit costs associated with the bid-ask spread. In this case potential arbitrage costs can be broken down into (1) the costs of opening and closing a futures position, (2) the costs of buying and selling spot bonds, and (3) the extra costs involved with holding a short position in physical bonds (Capozza \& Cornell 1979). According to Capozza and Cornell (1979), the first two costs are minimal, and should account for a differential of no more than 3 to 5 basis points between futures and forward rates. The third cost is more significant. To borrow government securities for shorting, dealers generally require that borrowers pay a premium on the borrowed securities. The existence of extra transaction costs implies that short-selling physical bonds can be expensive, and hence the differential between forward and futures rates can increase as a result (Capozza \& Cornell 1979). Overall, the results indicate that the mean pricing error is negative, consistent with the more expensive transaction costs boundary which involves short selling the underlying bonds.

Table 3:

3 and 10 Year Australian Commonwealth Government Bonds Pricing: Spot vs Futures Markets Time-toMaturity)

\begin{tabular}{|c|c|c|c|c|c|c|}
\hline \multirow[b]{2}{*}{$\begin{array}{l}\text { Trading Days } \\
\text { to Maturity }\end{array}$} & \multicolumn{3}{|c|}{ Panel A: 3 Year CGB } & \multicolumn{3}{|c|}{ Panel B: 10 Year CGB } \\
\hline & $\begin{array}{l}\text { Average } \\
\text { Mispricing }\end{array}$ & $\begin{array}{l}\text { Standard } \\
\text { Deviation }\end{array}$ & $\begin{array}{c}\text { Percentage } \\
\text { Difference in } \\
\text { Value }\end{array}$ & $\begin{array}{c}\text { Average } \\
\text { Mispricing }\end{array}$ & $\begin{array}{l}\text { Standard } \\
\text { Deviation }\end{array}$ & $\begin{array}{c}\text { Percentage } \\
\text { Difference in } \\
\text { Value }\end{array}$ \\
\hline 0 & -0.25 & 1.04 & $0.013 \%$ & -0.04 & 1.32 & $0.003 \%$ \\
\hline 5 & -0.98 & 1.36 & $0.022 \%$ & -0.74 & 1.94 & $0.055 \%$ \\
\hline 10 & -0.60 & 1.61 & $0.016 \%$ & -0.88 & 2.12 & $0.065 \%$ \\
\hline 15 & -1.15 & 1.63 & $0.031 \%$ & -0.86 & 2.27 & $0.064 \%$ \\
\hline 20 & -1.47 & 1.66 & $0.040 \%$ & -1.11 & 2.19 & $0.082 \%$ \\
\hline 25 & -1.57 & 2.19 & $0.042 \%$ & -1.31 & 2.28 & $0.097 \%$ \\
\hline 30 & -1.92 & 2.19 & $0.052 \%$ & -0.95 & 2.49 & $0.070 \%$ \\
\hline 35 & -2.06 & 2.73 & $0.056 \%$ & -1.37 & 2.15 & $0.102 \%$ \\
\hline 40 & -2.08 & 2.91 & $0.057 \%$ & -1.32 & 2.15 & $0.098 \%$ \\
\hline 45 & -2.24 & 3.04 & $0.063 \%$ & -1.42 & 2.26 & $0.106 \%$ \\
\hline 50 & -2.68 & 2.89 & $0.074 \%$ & -1.44 & 2.21 & $0.108 \%$ \\
\hline 55 & -2.77 & 2.97 & $0.075 \%$ & -1.45 & 2.40 & $0.108 \%$ \\
\hline 60 & -2.98 & 2.82 & $0.081 \%$ & -1.60 & 2.11 & $0.120 \%$ \\
\hline
\end{tabular}

Table 3 presents the mispricing of 3 and 10 year Australian Commonwealth Government Bond Futures by time-to-expiry. It shows the average mispricing of all the 
contracts up to 60 trading days from expiry in 5 trading-day increments. The sample includes 30 contract expiries from March 2002 to June 2009. (Yield Divergence = Average Forward Yield of Bond Basket - Futures Contract Yield). Negative (positive) divergence means that the underlying bonds are more (less) expensive than the futures. The table shows average mispricing and standard deviation in terms of basis points. The last column of each panel shows the mispricing in terms of percentage difference in value that arises from the yield divergence.

The pricing deviations averaged across contract expiries are shown in Table 3. The results for the 3 and 10 year bond futures contracts are presented in Panel A and Panel B, respectively. The results extend to 60 trading days (approximately 12 weeks) prior to contract expiry. Table 3 shows average mispricing, absolute mispricing and standard deviation in terms of basis points. The last column of each panel shows the mispricing in terms of percentage difference in value that arises from the yield divergence. We find a decreasing pattern of mispricing towards expiry. Arbitrageurs require greater compensation to act upon deviations from theoretical pricing levels when the risks they face are higher, permitting larger deviations to be sustained early in the futures expiry cycle (also time value of money). Consistent with the bond futures study by Rendleman \& Carabini (1979), greater absolute magnitudes of mispricing for longer times to maturity are observed in stock index futures markets, and are consistent with arbitrage being more risky further out from maturity (MacKinlay \& Ramaswamy 1988; Yadav \& Pope 1994).

\section{Table 4}

Regression Estimation on the Mispricing of 3 and 10 Year Australian Commonwealth Government Bonds Futures

\begin{tabular}{|c|c|c|c|c|c|c|}
\hline \multirow[b]{2}{*}{ Variable } & \multicolumn{3}{|c|}{ Panel A: 3 Year CGB } & \multicolumn{3}{|c|}{ Panel B: 10 Year CGB } \\
\hline & $\begin{array}{l}\text { Parameter } \\
\text { Estimate }\end{array}$ & t Value & $\operatorname{Pr}>|t|$ & $\begin{array}{l}\text { Parameter } \\
\text { Estimate }\end{array}$ & t Value & $\operatorname{Pr}>|t|$ \\
\hline Intercept & 0.182 & 1.110 & 0.267 & 1.458 & 10.850 & $<.0001$ \\
\hline MON & 0.050 & 0.360 & 0.722 & -0.006 & -0.060 & 0.955 \\
\hline TUE & 0.262 & 1.890 & 0.059 & 0.048 & 0.430 & 0.667 \\
\hline WED & 0.028 & 0.210 & 0.835 & 0.013 & 0.110 & 0.909 \\
\hline THU & -0.031 & -0.230 & 0.819 & 0.062 & 0.570 & 0.571 \\
\hline JUN & 0.050 & 0.410 & 0.681 & 0.297 & 3.050 & 0.002 \\
\hline SEP & -0.390 & -3.160 & 0.002 & -0.487 & -4.910 & $<.0001$ \\
\hline DEC & 0.199 & 1.590 & 0.112 & -0.824 & -8.300 & $<.0001$ \\
\hline Time-to-Expiry & 0.012 & 8.660 & $<.0001$ & 0.003 & 2.630 & 0.009 \\
\hline Volatility & 1342.8 & 17.360 & $<.0001$ & 387.9 & 5.930 & $<.0001$ \\
\hline
\end{tabular}

The regressand is the absolute mispricing measured in terms of basis points. After controlling for day of the week and expiry cycles, volatility of futures prices and time-toexpiry of contract are regressed upon mispricing.

We analyse the behaviour of the mispricing series in relation to market volatility and time to expiry, after controlling for day of the week and expiry cycles. As shown in Table 4, both volatility and time to expiry exhibit a significant positive relationship with the absolute level of mispricing. 


\section{Conclusion}

This paper presents an empirical investigation of the efficiency of futures markets. Since methods of pricing and settling government bond futures contracts varies significantly across countries, one of the motivations of the study is to document the method used to price, and evaluate efficiency of the 3 and 10 Year Australian Treasury Bond Futures contracts against underlying bonds. Results indicate that the futures contracts exhibit minimal variation from their theoretical value. The average mispricing equates to 1.96 basis points for 3 year, and 1.19 basis points for 10 year, government bond futures contracts. However, we find greater pricing inefficiencies for contract expiries during some periods (including the financial crisis of 2008), where the futures contract is underpriced compared to the underlying. This is mainly due to increased volatility and demand for government securities during the crisis, and the transaction costs involved with shorting the physical bonds.

Consistent with the more expensive transaction costs boundary which involves short selling the underlying bonds, mispricing is generally negative. Consistent with prior literature, we find a decreasing pattern of mispricing towards expiry. Yields on the futures contract and average forward yields of the underlying bond basket converge as the contract approaches expiry. After controlling for day of the week and expiry cycles, both volatility and time-to-expiry exhibit a significant positive relationship with the absolute level of mispricing.

\section{References}

Australian Securities Exchange Sydney Futures Exchanges Procedures, Determinations and Practice Notes

Brailsford, T \& Hodgson, A 1997, 'Mispricing in stock index futures: A re-examination using the SPI', Australian Journal of Management, vol.22, no.1 pp21-46.

Branch, B 1978 'Testing the unbiased expectations theory of interest rates', Proceedings of the Eastern Finance Association

Capozza, D \& Cornell, B 1979, 'Treasury Bill pricing in the spot and futures market', Review of Economics and Statistics, vol.61, pp513-520. http://dx.doi.org/10.2307/1935783

Cornell, B, 1981, 'Taxes and the pricing of Treasury Bill Futures Contracts: A note', Journal of Finance, vol.3, no.6, pp1169-1177. http://dx.doi.org/10.1111/j.1540-6261.1981.tb01083.x

Cox, JC, Ingersoll, J \& Ross, SA 1981, 'The relation between forward prices and futures markets', Journal of Financial Economics, vol.9. pp321-346. http://dx.doi.org/10.1016/0304-405X(81)90002-7

Cummings $\mathrm{J}$ \& Frino A 2008a, 'Index arbitrage and the pricing relationship between Australian stock index futures and their underlying shares, Working Paper.

Cummings, JR \& Frino, A 2008b, 'Tax effects on the pricing of Australian stock index futures’, Australian Journal of Management, vol.33, no.2, pp391-406. http://dx.doi.org/10.1177/031289620803300209

Elton, EJ, Gruber, MJ \& Rentzler, J 1984, 'Intra-day test of efficiency of the Treasury Bill Futures Market’, Review of Economics and Statistics, vol.66, no. 1. pp129-137. http://dx.doi.org/10.2307/1924704

Heaney, R \& Layton, A 1996, 'A test of the cost of carry relationship for the Australian 90 day bank accepted bill futures market', Applied Financial Economics, vol. 6, pp143153. http://dx.doi.org/10.1080/096031096334376 
Lang, RW \& Rasche, RH 1978. 'A comparison of yields on futures contracts and implied forward rates', Federal Reserve Bank of Saint Louis Monthly Review, vol.50,pp 21-30

MacKinlay, AC \& Ramaswamy, K (1988). 'Index-futures arbitrage and the behavior of stock index futures prices', The Review of Financial Studies, vol. 1 (2): pp 137-158. doi:10.1093/rfs/1.2.137

Poole, W 1978, 'Using T-bill futures to gauge interest rate expectations', Federal Reserve Bank of San Francisco Economic Review, Spring, pp7-18.

Puglisi, DJ 1978, 'Is the futures market for Treasury Bills efficient?', The Journal of Portfolio Management, Winter, pp64-67. http://dx.doi.org/10.3905/jpm.1978.64

Rendleman, RJ \& Carabini CE, 'The efficiency of the Treasury Bill futures market', Journal of Finance, vol.34, pp895-914. http://dx.doi.org/10.1111/j.1540-6261.1979.tb03443.x

Vignola, AJ \& Dale, CJ 1979, 'Is the futures market for Treasury Bills efficient?', Journal of Portfolio Management, Winter, pp76-81.

Yadav, PK. \& Pope, Peter (1994) 'Stock index futures mispricing: profit opportunities or risk premia?’ Journal of Banking and Finance, 18 (5). pp 921-953. 